\title{
Mateusz Falkowski
}

\section{Jak możliwa (do pomyślenia) jest dobrowolna niewola? O nowożytnych formach rządzenia, ideologii i spektaklu władzy}

Słynne dzieło Étienne’a de La Boétie Rozprawa o dobrowolnej niewoli ${ }^{1}$ sprawia wrażenie nieco anachronicznego - tworzone w momencie przełomu, to znaczy przejścia od rozkładającego się feudalizmu, przez tak zwane renesansowe monarchie administracyjne, do wczesnonowożytnych państw z barokowymi absolutyzmami na czele ${ }^{2}$, już w trakcie represji hugenotów,

Mateusz Falkowski (ORCID: 0000-0002-2584-6008) - doktor nauk humanistycznych, absolwent Międzywydziałowych Indywidualnych Studiów Humanistycznych Uniwersytetu Warszawskiego. Magisterium i doktorat obronił w Instytucie Filozofii Uniwersytetu Warszawskiego. Wykładowca w Instytucie Kultury Uniwersytetu Jagiellońskiego oraz poznańskiej School of Form; prezes Zarządu Fundacji na rzecz Myślenia im. Barbary Skargi. Autor książek: Kryteria sprzedajnej manifestacji (wspólnie z Markiem Sobczykiem, 2013), O maszynach, t. 1: Wiek XVII a filozofia techniki (2014), Twórca i perspektywy (2014), Manifesty kina grawitacyjnego (wspólnie z Markiem Sobczykiem, 2017). Współtwórca kina grawitacyjnego; w latach 2005-2014 działał w ramach warszawskiej inicjatywy kulturotwórczej „Orgia Myśli”. Kontakt: mathius2@wp.pl

1 É. de La Boétie, Rozprawa o dobrowolnej niewoli, przeł. K. Matuszewski, Stowarzyszenie Inicjatyw Wydawniczych, Katowice 2008.

2 Na temat tak zwanych monarchii renesansowych zob. klasyczne omówienie Jana Baszkiewicza w: idem, Powszechna historia ustrojów państwowych, Arche, Gdańsk 1998 (zwłaszcza s. 161-170); na temat specyfiki barokowych absolutyzmów zob. oryginalne i całościowe ujęcie 
a u progu wojen religijnych we Francji, traktuje o tyranii. Nie zostało jednak napisane ani w duchu nieco wcześniejszych rozważań Machiavellego o Księciu, to znaczy nie ma w nim poszukiwań skutecznego modelu panowania, ani też w stylu przyszłych prawniczo-filozoficznych koncepcji suwerenności, to znaczy nie ma w nim troski o jedność i spójność racjonalnie ugruntowanego państwa. Nie chodzi w nim ani o efektywne utrzymanie władzy, ani o zachowanie społecznego spokoju. Jeszcze pod wieloma innymi względami jest to dziełko niemachiavellowskie i niehobbesowskie.

\section{1}

Rozprawa La Boétiego, co być może najistotniejsze, jest pisana z perspektywy poddanych, nie władcy czy władzy. To znaczy, z jednej strony, sami poddani są tu przedmiotem zainteresowania, z drugiej - to ich oczami spoglądamy na zwierzchnika. Ten punkt widzenia w trakcie wywodu momentami się zmienia ${ }^{3}$, ale ogólne nastawienie jest jednoznaczne. Autora interesują źródła uległości - jak to się dzieje, że poddani są posłuszni swemu władcy, zwłaszcza zaś jego wersji tyrańskiej. To ważne - coś, co moglibyśmy nazwać „modelem tyrana”, implikuje: (a) bardziej personalny niż stricte suwerenny wzorzec władzy, której nie musi ucieleśniać konkretna osoba, a przeto (b) silniej podkreśla jej czysto fizyczny, rzeczywisty czy wręcz materialistyczny charakter. Zagadkę stanowi tu siła bezsilnego, pochodzenie przewagi, jaką jeden ma nad wielością. Rozprawa jest dlatego dziełem wyraźnie pośredniowiecznym: odziera lub raczej postrzega już monarchę odartego z wszelkich dodatkowych, nieziemskich przymiotów. Król jest nagi. Trochę jak władza duchowna z perspektywy „reformatorów”.

Ernsta Hinrichsa w: idem, Fürsten und Mächte. Zum Problem des europäischen Absolutismus, Vandenhoeck \& Ruprecht, Göttingen 2000.

3 Chodzi zwłaszcza o te fragmenty, w których La Boétie rozważa stosowane przez tyrana techniki i sposoby utrzymania poddanych w stanie podległości (zob. É. de La Boétie, Rozprawa..., s. 24-29).

4 Król jest nagi - dodajmy - już i jeszcze, to znaczy jego status nie opiera się ani na teologicznym oszustwie wcielenia, ani na ziemskim micie reprezentacji. Przyjmijmy, że „tyran” to nazwa instancji, która nie reprodukuje fikcji boskiego pomazańca, ale też nie sankcjonuje hipotezy o delegowaniu mocy i uprawnień. W obu przypadkach zakłada się w punkcie wyjścia istnienie zasadniczej więzi między władcą a poddanymi (relację panowania i poddaństwa lub - 
Co charakterystyczne, La Boétie nie poprzestaje na łatwych rozwiązaniach - przeciwnie, wyraźnie stosuje technikę retorycznego pogłębiania zagadkowości tytułowej „dobrowolnej niewoli”. Każda odpowiedź czy choćby sugestia odpowiedzi zapowiada jedynie poważniejsze trudności. Łatwiej uwierzyć - powiada - w niemal cudowne świadectwa odwagi i przywiązania do wolności (pochodzące z historii starożytnej) niż w fakt, iż jedna osoba gnębi masę innych ludzi: „w to, co zdarza się zawsze i wszędzie - że mianowicie jeden człowiek gnębi sto tysięcy ludzi, pozbawiając ich wolności - któż mógłby uwierzyć, gdyby tylko o tym słyszał, a tego nie widział?" ${ }^{2}$. Zabawnie brzmią liczbowe hiperbole stosowane przez La Boétiego: nie tysiąc ludzi, ale sto krajów, tysiąc miast, milion ludzi, powtarzane w różnych wersjach przynajmniej kilkakrotnie ${ }^{6}$. W takim przypadku nie może więc chodzić o brak charakteru, nie o tchórzostwo. Równolegle potwierdza się czysto materialny, fizyczny status władcy - gdyby nie poddani, tyrani byliby nadzy i rozbrojeni (ich fizyczności nie wzmacnia już żadna moc niefizyczna czy nadfizyczna). W istocie bowiem - zdaje się mówić autor - panujący zawdzięcza poddanym nie tylko swój status tyrana. Bez nich byłby niczym nawet fizycznie - jak gałąź, której nie żywią korzenie. Tyran objawia się tu nie w aurze pomazańca, nie w świetle krwawego spektaklu, nie w blasku splendoru - krótko mówiąc, nie w ramach autoekspozycji; prędzej w spojrzeniu Andersenowskiego dziecka, jako najnędzniejsza, najnikczemniejsza figura: „Ów pan ma jednak tylko dwoje oczu, dwie ręce, ciało i nie posiada niczego ponadto, czym dysponuje ostatni spośród mieszkańców naszych licznych miast"”.

W zasadzie już w samym mechanizmie utrudniania sobie odpowiedzi na postawione pytanie tkwi poniekąd jej część - jeśli wszystko, czym jest tyran, pochodzi od poddanych ${ }^{8}$, jeśli podległość stanowi tak naprawdę

domniemanych - skutku bądź zjawiska i przyczyny lub racji). Wybór perspektywy poddanych można więc rozumieć i w ten sposób: w punkcie wyjścia obowiązuje brak relacji, obcość. Jej korelatem jest właśnie „nagość”. Oczywiście, już tu widać wyraźnie, że relacja może przyjąć tylko materialny, fizyczny charakter. Zob. dalej.

5 Ibidem, s. 10.

6 Por. np. ibidem, s. 9.

7 Ibidem, s. 12.

8 „Czy ma nad wami władzę, która nie pochodziłaby od was?” (ibidem). 
jednostronny dar, a nie relację, to znaczy jeżeli w istocie jest relacją darującego do swego własnego daru, wówczas nie ma innego źródła niż właśnie ów akt darowywania. Ta odpowiedź, jak wiemy, nie jest ostatecznym rozwiązaniem. Tymczasem La Boétie stwierdza jedynie, że wystarczyłoby nie dawać, aby tyrania upadła. Nie dawać, czyli tak naprawdę nie chcieć dawać. Wystarczy postanowić, by się uwolnić. Nie trzeba przeciw tyranowi występować, przeganiać go, trzeba jedynie przestać go podtrzymywać.

Zauważmy, że odsłania się tu - co ciekawe, źródłowo właśnie w kontekście politycznym - typowo wczesnonowożytna problematyka etyczna: relacji między chceniem, wolą a praktyką, za moment ściśle wyeksplikowana przez Kartezjusza i Pascala, a nieco później przez Kanta. W zasadzie nie ma tu jeszcze mowy o kłopotach z przejściem od chcenia do działania („chcę, ale nie mogę, nie potrafię”), o tym typie problemów, które Kartezjusz rozwiąże $\mathrm{w}$ teorii manipulacji chceniami, z kolei Pascal ominie $\mathrm{w}$ koncepcji wiary jako fuzji rozumu strategicznego i praktyki ${ }^{9}$.

9 Zauważmy na marginesie, że w obu przypadkach zarysowuje się już typowy dla głównego nurtu myśli nowożytnej pragmatystyczny z ducha program etyki (etyki, która tym właśnie różni od moralności, że wiąże się przede wszystkim ze sferą praktyk podmiototwórczych, podczas gdy ta druga odsyła raczej do statycznej relacji między podmiotem a zasadami postępowania, myślenia itd., przy czym - co jeszcze ważniejsze - praktyki te, zwłaszcza w rozwiniętej wersji Kantowskiej, obejmują również aktywny, sensotwórczy stosunek do pojęć etycznych, podczas gdy moralność wymagałaby raczej jedynie skutecznej aplikacji trwałych reguł). Niezależnie od szeroko komentowanych kłopotów z naturą relacji ciała i duszy (w tym również ze statusem osławionego "gruczołu”) Kartezjusz trzeźwo zdaje sprawę z niebezpośredniego charakteru wpływu aktów woli na działania podmiotu. Przejście, które się tu każdorazowo dokonuje, dałoby się sprowadzić do nieco karkołomnej formuły: wiedzieć, czego chcieć, aby zaszło to, czego się chce (na przykład raczej chcieć się przywitać niż w taki lub inny sposób dotknąć czyjejś ręki). Zagadnieniom tym poświęcone są zwłaszcza Kartezjuszowskie Namiętności duszy (przede wszystkim rozdział XLV). Zob. R. Descartes, Namiętności duszy, przeł. L. Chmaj, Państwowe Wydawnictwo Naukowe, Warszawa 1986). Podobnie rzecz się przedstawia u Pascala - mimo wszelkich zastrzeżeń wobec jednostronności „kartezjanizmu” - u którego działanie wynika nie tyle z moich chceń, ile z rozumowania, ucieleśniającego się właśnie kosztem realizacji pragnień (uwierzyć to porzucić bezpośrednią substancjalność uczuć na rzecz formalizmu materialnych praktyk). Zauważmy na marginesie, że teoria kartezjańska może stanowić źródło rozwiązania niewysłowionego przez Pascala kłopotu: jak zmusić się 
$\mathrm{Z}$ drugiej strony mamy tu już nie mniej przenikliwe rozpoznanie kłopotów z samym chceniem - czasami ludzie, i tak jest w przypadku wolności od tyranii, nie maja sity pragnąc, brakuje im zwykłej chęci. Przenikliwość, która zbliża rozważania La Boétiego do analiz Kantowskich, polega tu, jak się zdaje, na tym, aby owej bezsiły nie traktować w obrębie antropologii czy etyki jednostkowej podmiotowości („co zrobić, by mieć siłę pragnąć?”), jak dzieje się to jeszcze u Kartezjusza i Pascala, ale w sferze uwarunkowań społecznych - podobnie jak koniec końców czyni to Kant w odniesieniu do swojej odwagi i oświecenia ${ }^{10}$.

Oddalmy możliwe skojarzenia z Hobbesowskim ujęciem relacji między władzą suwerenną a jednostkowym chceniem. Można by na przykład interpretować konflikt między dobrze określoną i zdefiniowaną (czyli racjonalną) wolą a chceniem - ów konflikt dający się być może sprowadzić do formuły: wiem, czego powinienem pragnać, ale nie potrafie tego chcieć albo jeszcze krócej: wiem, czego chcę, ale nie chce mi się - jako pewien pozór bądź objaw w obrębie jednostki istotnie zachodzącego zderzenia między delegowaną ongiś (faktyczny status owej delegacji - prawdziwej czy jedynie założonej - nie ma większego znaczenia ${ }^{11}$ ) mocą a tym, co po owej delegacji pozostaje $\mathrm{w}$ delegującym. Dla Hobbesa to zderzenie jest nieuchronne, ponieważ tak naprawdę oznacza nie tyle starcie dwóch różnych i równorzędnych stron, ile stan reprezentacji jednej przez drugą. Tym zresztą różni się tak zwany stan natury od sytuacji prawnie usankcjo-

ostatecznie do rozpoczęcia wyrozumowanej praktyki? Innymi słowy: jak przejść od w pełni wyznawanego przekonania („prawdy”) do czynu? Kłopot ten wynika po części z faktu, że w koncepcji Pascala do pewnego stopnia to właśnie praktyki wyrażają przekonania.

10 W przypadku Kanta działanie, do którego zmierza człowiek oświecony jest zarówno praktyką mentalną (odwaga myślenia), jak i od razu materialną (zerwanie z działaniami podług wskazań przewodników). Ta więź nieco przypomina rozważania Pascalowskie, choć zakłada już konkretne warunki organizacji zbiorowości.

11 A to, że potencjalnie jest ona jedynie założona, wręcz doskonalej koresponduje z jej racjonalnym, to znaczy niematerialnym, a przeto ahistorycznym, atemporalnym charakterem: $\mathrm{w}$ ten sposób wszelka ingerencja zwierzchniej władzy suwerennej to równocześnie każdorazowo i realnie zachodzące zakładanie niegdysiejszej delegacji $i$ jej legitymizacja. Nie ma sensu „przypominać” żadnego faktu delegacji, skoro - jako idealna i racjonalna - nie leży ona w obszarze faktów, lecz właśnie racjonalnych postulatów, które zawsze wymagać będą jedynie ponownych ustanowień (faktów o statusie ustanawiania założeń). Z tego punktu widzenia zaszczyty i tytuły przyznawane wybitnym poddanym nie różnią się od karania tych nieposłusznych. 
nowanego pokoju. „Wojna” to przede wszystkim potencjalna niejasność co do tego, kto jest kim, to znaczy w czym się wyraża jego wola (czego chce) - zaprowadzenie pokoju to ustanowienie instancji reprezentacji, zarazem więc tego, co reprezentowane. Jeśli dla La Boétiego natura nie jest polem walki, to dlatego, że jest ona raczej mieszaniną, a wszystko zmierza do zlania się w jedno ciało ${ }^{12}$. Dla Hobbesa jedność zawsze jest czymś sztucznym, ponieważ wymagającym reprezentanta (jego brak to synonim wojny, zawsze o tyle potencjalnej, będącej zagrożeniem-horyzontem, bo zawsze myślanym już z perspektywy reprezentacji). Dlatego dla La Boétiego mowa jest ważnym narzędziem komunikowania się, interakcji i wymiany, nie zaś ekspresji czy reprezentacji (słowo - zwłaszcza to w postaci umowy - jako reprezentant ujednoliconych dzięki niemu chceń ${ }^{13}$ ).

\section{3}

Brak sit, by pragnać - który to brak niweluje z kolei brak w osobie tyrana, dając mu siłę do władania, to znaczy wkładając weń to, czemu będzie się służyć - wynika z warunków urodzenia, dorastania i życia. Nawyk, przyzwyczajenie - oto właściwe przyczyny nienaturalnej gnuśności. Z kolei ograniczenie wymiany myśli i ograniczenie swobody mówienia to najlepsze metody utrzymania tego stanu (w sumie to nic innego jak ograniczenie kontaktów, czyli istoty wolności ${ }^{14}$ ). Tu, jak widzimy, następuje zmiana perspektywy - La Boétie rozważa techniki tyrańskie. Drugą są wszelkie sposoby odurzania i oczarowywania: tradycyjne igrzyska i sakralizacja - spektakl władzy, która zawsze przychodzi z zewnątrz. To powiązanie wrodzoności i transcendencji, nawyku i narkotyku tworzy skuteczny

12 Zob. É. de La Boétie, Rozprawa..., s. 14.

13 Można by zauważyć, nieco upraszczając, że ta relacja między słowem a chceniami nieprzypadkowo jest analogiczna do relacji między suwerenem a działaniami poddanych. W obu przypadkach instancja reprezentowania pozwala ukonstytuować się temu, co reprezentowane, jako pewnej jedności (kim jesteś albo czego chcesz).

14 Wolność - mimo że ujawniająca się w klasycznie, zdawałoby się, pojętej swobodzie wypowiedzi - nie polega przede wszystkim na ekspresji, która ewentualnie może naruszać inne wolności, ograniczając ich potencjał ekspresyjny, lecz na kontakcie, wymianie, komunikacji między równymi sobie („Wszyscy jesteśmy w naturalny sposób wolni, skoro jesteśmy równi”. É. de La Boétie, Rozprawa..., s. 14). 
mechanizm deprawacji. Nie ma tu, jak widzimy, miejsca na jakiekolwiek realne powiązanie między rządzącym i rządzonymi - władza jako coś, co już na nas czeka przy narodzinach lub co spada na nas „z góry”, będąca dla nas łonem i nieboskłonem, jakkolwiek dojmująca czy okrutna, nijak nie dotyka samych poddanych. Nie ma tu komunikacji, co najwyżej wymiana bodźców.

A jednak sedno rozwiązania tytułowego zagadnienia odsłania La Boétie dopiero w ramach swojej teorii zauszników albo dostępu do tyrana. Dopiero tu wskazuje też na immanentne czynniki panowania. I znów epatuje liczbami: sześciu ma pod sobą sześciuset, ci z kolei sześć tysięcy ${ }^{15}$ - a to za sprawą tego nieprzerwanego łańcucha, którego trwałość opiera się na tworzeniu urzędów, godności, funkcji i służb; w sumie może się okazać, że niemal połowa poddanych otrzymuje jakieś benefity ${ }^{16}$.

\section{4}

Przyjrzyjmy się raz jeszcze dziełku La Boétiego na szerszym tle rozwoju ówczesnej myśli politycznej. Niccolò Machiavelli, jakkolwiek trzeźwy i pozbawiony złudzeń, projektował idealne metody rządzenia dla Księcia mającego utrzymać czysto zewnętrzne panowanie. Thomas Hobbes uzasadniał sztuczną jedność suwerena, który w stosunku do poddanych pozostawał instancją transcendentną. Z kolei powstające mniej więcej równolegle polityczne (nie filozoficzne czy prawne) teorie rządzenia powoli zaczynały już traktować rzeczy i ludzi jako zasoby ${ }^{17}$. La Boétie - skupiając się na poddanych - diagnozuje poniekąd desakralizację Księcia, o czym świadczy do pewnego stopnia pominięcie kwestii ustrojowych i skupienie

Zob. ibidem, s. 29.

16 Rodzący się za moment we Francji absolutyzm opierał się w dużej mierze na wciąż poszerzanym gronie beneficjentów, sprzedaży urzędów i tytułów - centralizacja ustrojowa postępowała na koszt awansujących nabywców rang i stanowisk. Choć nobilitacje, głównie bogatszych warstw mieszczańskich, rozpoczęły się przynajmniej za czasów Ludwika XI. Por. J. Baszkiewicz, Historia Francji, Ossolineum, Wrocław 1999, s. 175; idem, Powszechna historia..., s. 165-166.

17 Na temat różnicy między teorią Księcia, doktryną suwerenności a nową „sztuką rządzenia” (ludźmi i rzeczami) zob. wykład Foucaulta z 1 lutego 1978 roku, w: M. Foucault, Bezpieczeństwo, terytorium, populacja, przeł. M. Herer, Wydawnictwo Naukowe PWN, Warszawa 2010. 
się na „modelu tyrańskim”. Jak gdyby przez krótki moment władca, pozostając przecież widoczny, stracił jednak boską sankcję, ukazując swój brak. Jest to moment, który trwa ledwie tyle, ile trzeba na lekturę kilkudziesięciu stron ${ }^{18}$ albo tyle, ile trwała ewolucja od monarchii administracyjnych do absolutystycznych. Teorię zauszników da się odczytać jako wyraz świadomości postępującego zanikania obnażonego uprzednio tyrana - zanikania albo, mówiąc językiem Gilberta Simondona, jego „konkretyzacji”19. Figura dotąd oderwana, starająca się „na siłę”, czysto mechanicznie zarządzać terytorium i poddanymi, wysyłając w tym celu do najdalszych zakątków królestwa swych urzędników, stopniowo traci słabą pozycję centralną, aby stać się, ale już niejawnie, rodzajem przekładni, kluczowego katalizatora procesów, nad którymi traci kontrolę bezpośrednią, którymi jednak może w coraz większym stopniu sterować, które może inicjować, potęgować, mobilizować. Bodaj najlepiej określa charakter owego procesu słówko „rozkład” ${ }^{20}$. Procesowi temu towarzyszyć będzie nowa, propagandowa wszechobecność monarszych wizerunków, odrestaurowana religia królów w zdecentralizowanym polu nowożytnych państw jako ośrodków sił. Ale owa obecność będzie już zupełnie inna niż ta niegdysiejsza, której niknącej siły był świadkiem La Boétie.

18 W wydaniu polskim niespełna trzydziestu.

19 Teorię konkretyzacji - w odniesieniu do obiektów technicznych - rozwinął Simondon w swoim słynnym traktacie poświęconym sposobom ich istnienia ( $D u$ mode d'existence des objets techniques). Obiekt (maszyna) staje się „konkretny”, gdy mechaniczne i jako takie abstrakcyjne złożenie jednofunkcyjnych składników zmienia się w wewnętrznie zintegrowany system powiązanych ze sobą licznymi zależnościami, o tyle też poniekąd wielofunkcyjnych elementów, dzięki czemu całość nie jest już czymś zasadniczo oderwanym od otoczenia, ale - przeciwnie - coraz silniej z nim połączonym, coraz adekwatniej, elastyczniej reagującym na bodźce zeń przychodzące. Obiekt techniczny zaczyna wówczas funkcjonować bardziej ekosystemowo, toteż nic dziwnego, że przypomina pod tym względem żywy organizm. Zob. G. Simondon, Die Existenzweise technischen Objekten, przeł. M. Cuntz, Diaphanes, Zürich 2012, s. 19-45.

20 Rozkład albo „naturalizacja”. Jeszcze Ludwik XIV powie do swego pierwszego ministra: „Każę panu robić to, co pan chce”. Świadomość własnego oderwania nie wykluczała przecież królewskich czy państwowych inicjatyw i inwestycji, czemu towarzyszyły merkantylistyczne poglądy na ekonomię. Z czasem te ingerencje w coraz większym stopniu - nade wszystko w warstwie doktrynalnej - zaczną przybierać postać regulacji. Gospodarcza physis rządzić się będzie odtąd własnymi prawami, których nie należy naruszać, a do których trzeba się raczej stosować. Wszelkie wykorzystanie zakłada najpierw dostosowanie. Opór, działanie „na siłę”, „ręczne sterowanie" to wyraz niewiedzy i zerwania z naturalnym środowiskiem. 
Moment ów można, za Michelem Foucaultem, określić mianem przejścia od suwerenności do dyscypliny i, niemal równocześnie, biopolityki, od reżimu teologiczno-personalnego do reżimu naturalistyczno-terytorialnego. Warto też zauważyć, że oznaczał on również powstanie luki na skutek zanikania bądź konkretyzacji tyrana między coraz gęstszą siecią instytucji i nowych praktyk rządzenia a spektaklem władzy. Z owej luki - to hipoteza - wyłoni się ideologia, która z tego punktu widzenia to nie po prostu zafałszowany, a ucieleśniony w praktykach mechanizm reprodukcji różnic społecznych („zawsze istniały ideologie..., „,zawsze funkcjonowały zafałszowujące wyobrażenia...”). Nowoczesna ideologia rodząca się w przerwie między mechanizmem rzadzenia a spektaklem władzy nieuchronnie wplątuje nas w „pozorne bunty”, „reprodukcję systemu” itp. Można ten fenomen określić jako zasadniczą nieprzejrzystość władzy nowoczesnej - dlatego na przykład barokowe frondy czy filipiki Henriego Saint-Simona z Pamiętników znamionują już ideologiczne uwikłania, swoiste qui pro quo - bunt przeciw koronie nie był wcale zerwaniem $\mathrm{z}$ „dobrowolną niewolą", jako że pozycje buntowników nie były tymi, z jakich oficjalnie występowali (szlachta rodowa). Tę nieadekwatność zapowiada już rozprawa La Boétiego - demaskatora tyrana, którego wówczas nigdzie nie było.

\section{Bibliografia}

Baszkiewicz J., Historia Francji, Ossolineum, Wrocław 1999.

Baszkiewicz J., Powszechna historia ustrojów państwowych, Arche, Gdańsk 1998. Boétie É. de La, Rozprawa o dobrowolnej niewoli, przeł. K. Matuszewski, Stowarzyszenie Inicjatyw Wydawniczych, Katowice 2008.

Descartes R., Namiętności duszy, przeł. L. Chmaj, Państwowe Wydawnictwo Naukowe, Warszawa 1986.

Foucault M., Bezpieczeństwo, terytorium, populacja, przeł. M. Herer, Wydawnictwo Naukowe PWN, Warszawa 2010.

Hinrichs E., Fürsten und Mächte. Zum Problem des europäischen Absolutismus, Vandenhoeck \& Ruprecht, Göttingen 2000.

Simondon G., Die Existenzweise technischen Objekten, przeł. M. Cuntz, Diaphanes, Zürich 2012. 


\section{How Is Voluntary Slavery Possible (Conceivable)? On the Modern Forms of Government, Ideology and the Spectacle of Power}

The article is devoted to the famous The Discourse of Voluntary Servitude by Étienne de La Boétie. The author considers the theoretical premises underlying the concept of "voluntary servitude", juxtaposing them with two modern concepts of will developed by Descartes and Pascal. An important feature of La Boétie's project is the political and therefore intersubjective - as opposed to the individualistic perspective of Descartes and Pascal starting point. It is therefore situated against the background of, on the one hand, the historical evolution of early modern states (from feudal monarchies, through so-called Renaissance monarchies up to European absolutisms) and, on the other hand - of the political philosophy of Machiavelli and Hobbes.

\section{Keywords:}

EARLY MODERNITY, POLITICAL PHILOSOPHY, THEORY OF WILL,

Étienne de La Boétie, René Descartes, Blaise Pascal,

Thomas HobBes, NicCOLÒ MACHIAVElli. 